\title{
AN IMPLEMENTATION OF PARTICIPATIVE IQRO METHOD IN THE ORIENTED OF AL-QURAN EDUCATION CENTER ON THE PURPOSE OF LEARNING GOAL AND OBJECTIVES FOR EARLY CHILDREN
}

(Case Study on the Group B Students of TPQ Assalam in West Bandung Regency)

\author{
Chandra Asri Windarsih \\ IKIP Siliwangi \\ chandraasriwd@yahoo.com
}

\begin{abstract}
Learning to read and write the Quran using the IQRO method has been used for a long time and applied to children. The basic reason is that with IQRO it is very easy for children to follow, the book is cheap consisting of six books that have a certain level. This research wants to collaborate with the learning goal method and objectives oriented. Hopefully, that early childhood is easy to understand and easy to remember letters, to be able to read the Quran correctly. Formulation of the problem "How is the application of participatory learning IQRO method in TPQ oriented to the purpose of learning activities for early childhood". The objective of the research is to find the general description, planning, implementation, and evaluation, participatory learning of the IQRO method in TPQ through the Learning Goal Method and Objectives Oriented on children. This research used a qualitative method with analytical descriptive. The researcher analyzes data, find information, relationships, basic frameworks, carefully compare, and report in narrative form. The result is that children who are included in participating and have goals in IQRO learning will be able to more quickly and master learning. Location of research in TPQ (Alquran Education Center) Assalam Pakusarakan Earth Complex II Rt 03/25 Tanimulya Ngamprah Kab. West Bandung.
\end{abstract}

Keywords: Participatory Learning, AlQuran Education Center, Early Childhood

\section{INTRODUCTION}

We must educate children from childhood. With the many ways or methods of learning in children's learning techniques are required to be able to prepare themselves to be human beings who succeed in school without forgetting spiritual intelligence. In the golden age, children begin to react to stimuli given either from themselves or from other people and their environment. This period of sensitivity children need the right conditions and stimulation so that children's growth and development is achieved optimally. This condition requires the role of educators (parents, teachers, or adults) who understand the development and potential of children, Santoso, (2018: 61). As an additional and complementary element (Complementary Education), Out of School Education presents subjects outside the curriculum. In harmony with the opinion of Santika (2016: 166-174). Participatory learning, in essence, can be interpreted as an effort of educators to include students in learning activities. Characteristics of participatory learning are: educators/teachers play a role only to help students to have initiatives to participate in learning activities, encourage students to find a comfortable atmosphere, conducive, fun, in learning, participating in group learning activities, supporting students to be able to increase the desire for achievement. 
The participation of students in learning through the stages of learning activities, namely the program planning stage (planning program), implementation (implementation program), evaluation (evaluation program) learning activities. Educators encourage students to find solutions (problem-solving). Learning Objectives (Learning Goals and Objectives Oriented), created with a framework that has been compiled and then formulated according to the needs of students without forgetting the experiences, abilities of children, environment, abilities, and seeing various backgrounds, opportunities, and obstacles that will be faced. With the aim to understand and express what must be prepared and done in participatory learning. One way to learn to read and write the Quran uses the IQRO method which has been used for a long time and applied to children. Irliana, 2016 stated that learning system with IQRO is very effective because anyone will find it easy and the level of difficulty is small so that old, young children easily learn, especially for those who have mastered reading, writing Arabic letters, and reciting will be felt pleasant. Some of the reasons that support this method are because it is widely used in kindergarten, TAAM, RA, TPQ even in the mosque. If IQRO one has finished then it will be continued with IQRO 2 and so on with Ebta first as a test to move volumes. Based on the findings in the field with the convenience obtained this study wants to collaborate with participatory learning programs with the aim of children easily understand learning to read the Quran. This is evident in their ability to recite or read the Quran which is smoother than reading Alfabeth's letters and some even do not recognize Alfabeth's letters but can recite. (Irliana, Faiqotul, Hikmah, et al, 2016: 206)

\section{THEORIES OF THE STUDY AND RESEARCH METHOD}

Islamic rule in education adheres to several methods for preparing and educating children with proper education and educating pious people at all times. Each of these methods has an effect on humans, especially for children, these methods move their feelings and direct them right on target, right according to the expectations of learning. As stated by Maghribi (2004: 367) in Saputra Rahmat (2014: 111), namely educators act as facilitators and pump up enthusiasm in participatory methods while children must play an active role and take initiative, and the teacher as a supporter. Things that are organized in learning include, organizing children's playgrounds, playing media, learning religion, sports, study schedules, and various kinds of learning activities. These things do not seem too complicated, but if not organized can lead to learning not optimal. According to Azwardi (2015: 108-114) Initially the role of educators was more dominant in providing children's needs, starting from the preparation of teaching materials and implementation to being guided over time, the child will begin to be released but still guided so that over time the child will begin to be released but still under the control of the educator can take the most effective and efficient learning initiative for him. The IQRO method prioritizes the personal abilities of each student. Every child has their own words depending on their ability and tenacity in learning. This difference is caused by the IQRO method not being classical but individually. Children who are creative, diligent, and study hard will be more racing results and cannot be equated with other children (Srijatun, 2017: 25). In research on the application of participatory learning IQRO methods in TPQ with the aim of children can participate in learning. This means to know, reveal, and examine the application of participatory learning IQRO methods in TPA that have learning objectives. The learning model can be interpreted as a patterned system to be used in compiling guidelines in the form of curriculum, prota, promes, arranging material, organizing learners, and choosing devices and systems in a learning condition, (Nasrun and Feriansyah, 2018: 671). This research used a qualitative method in the form of a complete description of what is done both in the form of speech, writing, behavior that can be observed, observed, from someone or group, community, institutions, and other organizations studied from 
various viewpoints that are complete and intact, comprehensive, holistic. With an analytical descriptive approach, do not use a measuring instrument. It is called naturalistic because the research is natural, not artificial and naturally it is not manipulated, experimented or tested. Qualitative research has many similarities to the characteristics in the Al-Quran education center. The similarity is to have a holistic, dynamic, and human characteristics, showing processes and meanings and based on empathy to capture and appreciate the perspective of the subject or participant being studied. Techniques for collecting data with case studies through observation, interviews, questionnaires, and documentation studies. Observations were made directly into the Al-Quran Education Center in the West Bandung Regency. Whereas for interviews conducted on organizers and teachers or ustadzah (female teacher) who teach and guide santri (students) in Al-Quran Education Center, West Bandung Regency. Questionnaires are used to collect a number of relevant data, consisting of questions, documentation studies, journals, research results, and a history of the implementation of the Al-Quran Education Center. So that program can be formulated to share information on how participatory learning methods of IQRO have goals in learning. The steps are taken (1) analyze field observations, (2) prepared research plans, (3) initial product developments, (4) trials, (5) improve initial products, (6)) main field tests (7) Revised product (8) Main test to see the results of product effectiveness, (9) Final revision (10) distribution and implementation., (Puspitorini, 2017: 333-341)

\section{RESULTS AND DISCUSSIONS}

Community education as an educational path that is close to the needs of the community, is no stranger to participatory learning that is always integrated into community education programs (Setiawan, 2015: 5). Al Quran Assalam Education Center as an out of school education has 63 students who are guided by 6 ustazah (female teacher) and one ustad (male teacher). For pre-kindergarten / early childhood children there were 27 people, and teenagers numbered 8 people, and elementary school children. Learning starts at 4:00 p.m. and finishes at 5:00 p.m. When learning the Quran is a lot of methods used from starting to learn alif, ba, ta, tsa, in surau-surau,tajuq, mushola (a small house for Islamic people pray), then found the faster IQRO method, the Albana method, the tilawati method, and many other methods. Learning is an activity carried out by teachers in certain conditions so that the cognitive, affective, and psychomotor of students change for the better (Bistari, 2018: 13). The uniqueness of IQRO that learning must be personal, not classical because every child has their own page so that its application can be applied maximally. Learning as an effort that has a system and is carried out by educators to create good conditions for children. Sometimes people generally only look at the results regardless of the process, while learning cannot be instant needing guidance, need to be motivated, need to be encouraged and continuous stimulus. Participatory learning activities arise from the use of effective strategies for children as an effort by educators to involve children in learning steps. The principle of objective and objective oriented learning that learning with participation techniques is planned and the implementation remains in the objectives that have been applied before.

Early childhood is directly involved and given the responsibility of completing one stage in the IQRO book in a certain period of time so that the child can be motivated and have a predetermined period. High ability of children to understand learning to read the Quran with IQRO is sometimes a child early experience difficulties so that must be assisted, guided, motivated, given a stimulus to achieve the correct goal that is to be able to read the Quran with the tartil. Because reading the Quran as a divine word must be truly tartil (related to the 
sound/ how to pronounce it), it must be in accordance with tajweed (related to the rule when reading Quran) which is to issue letters from its place and the letter must be appropriate.

The steps taken in stages are to guide children in developing participatory learning activities with the following objectives:

a. Helping children to make a pleasant learning atmosphere not bored.

b. Helping children make groups and study groups.

c. Helping children create an effective framework of learning design.

d. Helping students in determining learning needs in their groups.

e. Helping students to be given time to share learning experiences.

f. Helps in assessing the results, processes, and effects of learning activities.

After being planned by the teacher and practiced using learning objectives with children's participation, the santri (students) of group B children had significant ease in memorizing letters and being able to read fluently. This non-formal learning turned out to be very helpful for children in group B to understand the right way with their participation in learning. Helping learning to make it easier for children who did not know to know, who were not interested in becoming interested, even supported by the many television programs that presented the amazing tahfidz-tahfidz (a person who memorized the Quran). It is expected that more and more young children can master the reading of the Quran. Because as parents, they want their descendants to survive in the afterlife.

\section{CONCLUSIONS AND RECOMMENDATIONS}

The global picture of the level of achievement of the implementation of participatory learning in the IQRO method in the Al-Quran Education Center has the aim of including children's participation in learning at first the child is still confused and feeling but over time early childhood is increasingly understood. For participatory planning of the IQRO method in the Al-Quran Education Center, which is oriented towards the goal by the way the child is involved, it can be prepared properly by the ustadzah (female teacher) and even if there are obstacles, either the children or their mentors can handle it well. Whereas the application of participatory learning in the IQRO method in the Al Quran Education Center which is oriented towards the learning objectives is when the child is confused because he has to determine and try to make the achievement but after the child is done it is more comfortable and understands the intent. Participatory learning evaluation method or IQRO system in TPQ Assalam which aims at learning by emphasizing the participation of the students, in this case, group B children need improvements to get maximum results. It is expected that by using this participatory method, a child can more easily learn IQRO in order to be able to read the Quran pleasantly and its application is easy in the field. As well as donating the right way to stimulate children with this method to practitioners in the Al Quran Education Center.

The suggestion is that there are still many Al-Quran Education Centers that are monotonous in their learning methods, traditional thinking is not developed, and the knowledge of educators is limited so that they are only stuck with one method or system without trying the other methods. There are also many obstacles that are felt by clerics and religious teachers in developing rapid, precise learning and achieving targets for children's learning. There needs to be a standard learning program that can support and provide training, training or courses for ustad (male teacher) and ustadzah (female teacher) so that participatory learning can be applied in the Al-Quran Education Center around the West Bandung Regency where the population is heterogeneous and is a new district. 
The general trend of the problem is that there are indications that the implementation of participatory learning in the IQRO method in the Al-Quran Education Center in West Bandung still has not touched it thoroughly, is still as it is, sober, not maximized, not yet grounded, not yet implemented in the Education Center Al Quran in the West Bandung Regency.

\section{BIBLIOGRAPHY}

Azwardi, PAUD Learning Management Education Manager Vol 9 No. 1 Maret 2015, hal: 108-114, https://ejournal.unib.ac.id/index.php/manajerpendidikan/article/download/1104/915

Himmah, F Irliana, Application of Iqro Method to Learning Calistung Citizens Learning Merpati Basic Functional Literacy, Pancaran vol 5 No. 4, November 2016, Hal: 201212, https://jurnal.unej.ac.id/index.php/pancaran/article/download/3780/2964/

Morrison S. George. 2012. Basics of Early Childhood Education, Jakarta, Indeks.

Nasrun, dkk, Mentoring Innovative Learning Models in Kec. Primary Schools Medan

Selayang Medan,Jurnal Pengabdian Kepada Masyarakat, Vol 24 No.2, April-Juni 2018, hal: 671-176, e ISSN 2502-7220

https://jurnal.unimed.ac.id/2012/index.php/jpkm/article/viewFile/10359/9302

Puspitorini, W. Fundamental Oriented Learning Model with Water Play for Children 5-6 Years, Jurnal Pendidikan Usia Dini, Vol 11 No. 2, November 2017, E 25030566https://doi.org/10.21009/jpud.112.11. http://journal.unj.ac.id/unj/index.php/jpud/article/view/4889

Santika T, Learning Management of the Creative Innovative Literacy Program (LKF) in Margamulya Village, Kec. Telukjambe Barat, Kab. Karawang, E Plus Eksistensi PLS Universitas Sultan Ageng Tirtayasa, Vol 1 No. 2 Agustus 2016, Hal: 166-174. http://jurnal.untirta.ac.id/index.php/E-Plus/article/view/1162/927

Santoso, Application of the Concept of Edutainment in Learning in PAUD, Inppendas Jurnal Ilmiah Kependidikan, ISSN 2615.5443 Vol 1 No.1 Februari 2018 hal: 61-68 https://jurnal.umk.ac.id/index.php/pendas/article/viewFile/2376/1361

Saputra, R , The Concept of Child Education in Islam At Tadib Jurnal Ilmiah Pendidikan Agama Islam, ISSN 2085-2525, Vol VI No. 1, April September 2014 http://staindirundeng.ac.id/wp-content/uploads/2015/10/jurnal-at-tadib-vol-6.pdf

Setiawan, WE, Participatory Learning Model in Increasing the Independence of Women as Heads of Familie, Universitas Negeri Palangkaraya, 2016 http://ejournal.upi.edu/index.php/pnfi/article/download/5587/3793

Sudjana. 2010. Out-of-School Education Learning Strategies. Bandung; Falah Production.

Law Nolte, Dorothy dan Rachel Harris, Children Learn from Their Lives World Classic Parenting Values, Translators:Helly Prajitno Soetjipto, Yogyakarta : Pustaka Pelajar, 2016

Lutfhi A,M dkk, Model of Religious Culture Education and Humanity, Nadwa Jurnal Pendidikan Islam, e 2502-8057, Vol 12 No.2, 2018, hal: 331-344 http://journal.walisongo.ac.id/index.php/nadwa

Yusuf Basuni B, Concepts and Effective Learning Indicators, Journal of Learning and Scientific Studies, Vol 1 No. 2, Oktober 2017-Maret 2018, hal: 13-20 http://jurnal.untan.ac.id/index.php/jurnalkpk/article/download/25082/75676576424 